tory Service must, however, not be spread over relatively unrewarding sectors of human disease. Virus isolation is a costly procedure in both materials and manpower. The outstanding problem of respiratory virus disease demands a great deal of further basic work in order to define resistance more clearly. The serious problem of infectious and serum hepatitis challenges all of us to greater efforts to obtain control over this infection. New and better vaccines are required against old enemies such as influenza, and the use of existing vaccines against poliomyelitis, measles, and rubella must continue to be pressed. Other vaccines, such as, for instance, mumps, may become worth while. Who can say what may have been achieved in this vast field of human disease in another thirty years? Certainly the present disappointment of chemotherapy against virus diseases cannot be accepted as final.

I am grateful to Drs. A. Roden and W. Dunnett, of the Department of Health and Social Security, for their help with the section on immunization and with the chart.

\section{References}

1 Cockburn, W. C., and Drozdov, S. G., Bulletin of the World Health Organization, 1970, 42, 405.

2 Beare, A. S., Bynoe, M. L., and Tyrrell, D. A. J., British Medical fournal, $1968,4,482$. ${ }^{3}$ Mills, J., Van Kirk, J., Hill, D. A., and Chanock, R. M., Bulletin of the

Slepuškin, A. N., et al., Bulletin of the World Health Organization, 1967, $36,385$.

Stuart-Harris, C. H., Archives of Environmental Health, 1970, 21, 276. Enders, J. F., Katz, S. L., Milovanovic, M. V., and Holloway, A., New England Fournal of Medicine, 1960, 263, 153.

Schwarz, A. J. F., American Fournal of Diseases of Children, 1962, 103, 386

Goffe, A. P., and Laurence, G. D., British Medical fournal, 1961, 2, 1244.

M.R.C. Measles Vaccines Committee, British Medical fournal, 1965, 1, 817 .

10 M.R.C. Measles Vaccines Committee, British Medical fournal, 1966, 1, 441.

1 M.R.C. Measles Vaccines Committee, British Medical fournal, 1968, 2, 449.

12 M.R.C. Measles Vaccines Committee, 1970, unpublished.

13 Miller, D. L., British Medical fournal, 1964, 2, 75.

is Parkman, P. D., Meyer, H. M., jun., Kirschstein, R. I Parkman, P. D., Meyer, H. M., jun., Kirschstein, R. L., and Hopps, H. E., New England fournal of Medicine, 1966, 275, 569

15 Peetermans, J., and Huygelen, C., Archiv für die gesamte Virusforschung, 1967, 21, 133.

16 Plotkin, S. A., Farquhar, J. D., Katz, M., and Ingalls, T. H., American Fournal of Epidemiology, 1967, 86, 468.

7 Dudgeon, J. A., Marshall, W. C., Peckham, C. S., and Hawkins, G. T., British Medical fournal, 1969, 1, 271.

18 Phillips, C. A., Maeck, J. V. S., Rogers, W. A., and Savel, H., fournal of the American Medical Association, 1970, 213, 624.

19 Dick, G., Progress in Medical Virology, 1966, 8, 1.

${ }^{20}$ Hilleman, M. R., Buynak, E. B., Weibel, R. E., and Stokes, J., jun., New England fournal of Medicine, 1968, 278, 227.

21 Smorodintsev, A. A., Klyachko, N. S., Nasibov, M. N., and Shickina, E. S., In Papers and Discussions presented at the 1 st International Confer-
. E. S., In Papers and Discussions presented at the 1st International Confer-
ence on Vaccines agaiust Viral and Rickettsial Diseases of Man, p. 422. ence on Vaccines agaiust Viral and Rickettsial Diseases of Man, p. 422. Washington, Pan American Health Organization, 1967.

Weibel, R. E., et al., fournal of the American Medical Association, 1969, 207, 1667.

23 Chanock, R. M., Science, 1970, 169, 248.

\title{
"For Debate...."
}

\section{Halothane Hepatitis -A Preventable Disease?}

\author{
PAUL SHARPSTONE, D. R. K. MEDLEY, ROGER W ILLIAMS
}

British Medical fournal, 1971, 1, 448-450

\section{Summary}

Eleven patients with acute hepatitis following multiple anaesthetics with halothane have been seen at two hospitals during the last four years. Six had massive hepatic necrosis and died. Unexplained fever occurred in nine of the patients; two of these and one other had had previous episodes of jaundice after halothane anaesthesia. Thus, in ten patients the disease could have been avoided.

\section{Introduction}

Numerous reports of acute hepatic necrosis occurring after anaesthesia with halothane followed the earliest mention of this association in 1958. ${ }^{2}$ Subsequently, large retrospective surveys $^{34}$ showed that this was a rare complication and that it occurred no more frequently after halothane than after

King's College Hospital, London S.E.5

PAUL SHARPSTONE, M.B., M.R.c.P., Senior Medical Registrar (Present address : Consultant Physician, Royal Sussex County Hospital, Brighton)

ROGER WILLIAMS, M.D., F.R.C.P., Consultant Physician and Director of Liver Unit

St. Margaret's Hospital, Epping, Essex

D. R. K. MEDLEY, D.M., M.R.c.P., Consultant Physician other anaesthetic agents. However, since there are several potential causes of liver failure in most patients who have had a surgical operation, it was not possible to implicate halothane as the specific cause in many of the reported cases. But the consistency of the clinical features, ${ }^{5}$ the recurrence of hepatitis after re-exposure ${ }^{67}$ the specificity of the histological changes seen on electron microscopy," and, in particular, the provocation of hepatitis by deliberate challenge of previously affected individuals ${ }^{89}$ leave little doubt that halothaneinduced hepatitis is an entity.

Though the reported mortality of 67 to $96 \%^{510}$ is probably biased because of the inclusion of more severe cases, halothane hepatitis must, nevertheless, be regarded as a very dangerous condition. However, its occurrence is still disputed by anaesthetists. ${ }^{11-13}$ This, together with our experience that at least some of the cases could have been avoided, prompted us to report the 11 patients seen at two hopsitals during the last four years.

\section{Clinical Features}

The clinical and laboratory data are summarized in the Table. Seven patients (Cases 1-7) were referred from other hospitals to a unit specializing in liver disease and four (Cases 8-11) were treated at a regional general hospital. Presumably the higher mortality of the former group is the result of the referral of more severe cases. 
Clinical and Laboratory Data of the 11 Patients Reported

\begin{tabular}{|c|c|c|c|c|c|c|c|c|c|c|}
\hline \multirow{3}{*}{$\begin{array}{l}\text { Case } \\
\text { No. }\end{array}$} & \multirow{3}{*}{$\begin{array}{c}\text { Age } \\
\text { (years) }\end{array}$} & \multirow{3}{*}{ Sex } & \multirow{3}{*}{ Underlying Disease } & \multirow{2}{*}{\multicolumn{2}{|c|}{ Halothane Anaesthesia Given }} & \multirow{3}{*}{$\begin{array}{c}\text { Interval } \\
\text { Between } \\
\text { Anaesthesia } \\
\text { and Onset of } \\
\text { Jaundice } \\
\text { (days) } \\
\end{array}$} & \multirow{3}{*}{$\begin{array}{c}\text { Postoperative } \\
\text { Pyrexia }\end{array}$} & \multicolumn{2}{|c|}{ Maximum Serum Levels } & \multirow{3}{*}{$\begin{array}{l}\text { Outcome (from } \\
\text { onset of jaundice) }\end{array}$} \\
\hline & & & & & & & & \multirow{2}{*}{$\underset{(\mathbf{m g} / \mathbf{1 0 0} \mathbf{~ m l})}{\text { Bilirubin }}$} & \multirow{2}{*}{\begin{tabular}{|c|}
$\begin{array}{c}\text { Aspartate } \\
\text { Aminotrans- } \\
\text { ferase } \\
\text { (IU/100 ml) }\end{array}$ \\
\end{tabular}} & \\
\hline & & & & Date & Surgical Procedure & & & & & \\
\hline 1 & 65 & $M\{$ & $\begin{array}{l}\text { Carcinoma of penis } \\
\text { Inguinal hernia }\end{array}$ & $\begin{array}{r}21.1 .69 \\
4.2 .69 \\
13.2 .69 \\
\end{array}$ & $\begin{array}{l}\text { Biopsy of carcinoma } \\
\text { Amputation of penis } \\
\text { Herniorrhaphy } \\
\end{array}$ & $\overline{4}$ & $\begin{array}{l}\text { No } \\
\text { Yes } \\
\text { Yes } \\
\end{array}$ & $\overline{32}$ & $\overline{\overline{1}} \overline{260}$ & Death after 18 days \\
\hline 2 & 20 & $\mathbf{M}$ & $\begin{array}{l}\text { Undiagnosed febrile } \\
\text { illness }\end{array}$ & \begin{tabular}{|l|}
9.5 .69 \\
6.6 .69 \\
20.60
\end{tabular} & $\begin{array}{l}\text { Muscle biopsy } \\
\text { Lymph node and liver biopsy }\end{array}$ & $\begin{array}{r}18 * \\
3 t\end{array}$ & $\begin{array}{l}\text { Pyrexial } \\
\text { throughout }\end{array}$ & $\left\{\begin{array}{l}5 \cdot 2 \\
15\end{array}\right.$ & $\begin{array}{l}120 \\
610 \\
\end{array}$ & Death after 22 days \\
\hline 3 & 37 & $M$ & $\begin{array}{l}\text { Degloving injury of } \\
\text { hand }\end{array}$ & \begin{tabular}{|l|}
22.9 .69 \\
13.10 .69 \\
\end{tabular} & $\begin{array}{l}\text { Hand surgery } \\
\text { Hand surgery }\end{array}$ & 3 & $\begin{array}{l}\text { Yes } \\
\text { Yes }\end{array}$ & 32 & 420 & Recovery in 41 days \\
\hline 4 & 60 & $\mathrm{~F}$ & Carcinoma of colon & \begin{tabular}{|r|}
17.12 .69 \\
31.12 .69 \\
13.1 .70 \\
\end{tabular} & $\begin{array}{l}\text { Hemicolectomy } \\
\text { Resuture of wound } \\
\text { Faecal disimpaction } \\
\end{array}$ & $\begin{array}{l}\overline{13} \\
+t\end{array}$ & $\begin{array}{l}\text { No } \\
\text { Yes } \\
\text { Yes } \\
\end{array}$ & $\overline{\overline{20}}$ & $\overline{432}$ & 年 \\
\hline 5 & 57 & F & Carcinoma of uterus & 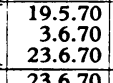 & $\begin{array}{l}\text { Dilatation and curettage } \\
\text { Insertion of radium } \\
\text { Total hysterectomy } \\
\end{array}$ & $\overline{\overline{4}}$ & $\begin{array}{ll}\text { No } \\
\text { Yes } \\
\text { Yes } \\
\end{array}$ & $\overline{\overline{20}}$ & $\overline{900}$ & Death after 4 days \\
\hline 6 & 57 & $\mathbf{F}$ & Cholelithiasis & \begin{tabular}{r|}
23.6 .70 \\
7.7 .70 \\
320.70
\end{tabular} & $\begin{array}{l}\text { Cholecystectomy } \\
\text { Drainage of subphrenic abscess }\end{array}$ & $\overline{3}$ & $\begin{array}{l}\text { Yes } \\
\text { Yes } \\
\end{array}$ & 25 & 435 & Death after 6 days \\
\hline 7 & 42 & F & Obesity & $\begin{array}{r}23.9 .70 \\
14.10 .70 \\
\end{array}$ & $\begin{array}{l}\text { Lipectomy right thigh } \\
\text { Lipectomy left thigh }\end{array}$ & $\overline{3}$ & $\begin{array}{l}\text { Yes } \\
\text { Yes }\end{array}$ & 41 & 840 & Death after 25 days \\
\hline 8 & 57 & $\mathbf{F}$ & Carcinoma of uterus & \begin{tabular}{|l|}
13.8 .68 \\
20.8 .68 \\
30.8 .68 \\
\end{tabular} & $\begin{array}{l}\text { Dilatation and curettage } \\
\text { Total hysterectomy } \\
\text { Resuture of wound }\end{array}$ & $\overline{\overline{6}}$ & $\begin{array}{l}\text { No } \\
\text { Yes } \\
\text { Yes }\end{array}$ & $\overline{\overline{11.5}}$ & $\overline{\overline{286}}$ & Recovery in $\mathbf{3 0}$ days \\
\hline 9 & 58 & $\mathrm{~F}$ & $\begin{array}{l}\text { Carcinoma of colon and } \\
\text { ovarian cyst }\end{array}$ & $\begin{array}{l}21.4 .67 \\
10.5 .67 \\
31.5 .67 \\
\end{array}$ & $\begin{array}{l}\text { Colostomy and oophorectomy } \\
\text { Colectomy } \\
\text { Closure of colostomy }\end{array}$ & $\frac{-}{12}$ & $\begin{array}{l}\text { Yes } \\
\text { Yes } \\
\text { Yes } \\
\end{array}$ & $\overline{\overline{6}}$ & $\overline{\overline{750}}$ & Recovery in 21 days \\
\hline 10 & 48 & F & $\begin{array}{l}\text { Varicose veins } \\
\text { Appendicitis } \\
\text { Cystadenoma of breast } \\
\text { Uterine polyp } \\
\text { Vesical calculi } \\
\end{array}$ & \begin{tabular}{rl|}
26.4 .65 \\
3.6 .65 \\
15.6 .67 \\
29.9 .67 \\
5.6 .68
\end{tabular} & $\begin{array}{l}\text { Stripping of veins } \\
\text { Appendicectomy } \\
\text { Excision of tumour } \\
\text { Dilatation and curettage } \\
\text { Cystoscopy }\end{array}$ & $\frac{10 *}{10 t}$ & $\begin{array}{l}\text { No } \\
\text { No } \\
\text { Yes } \\
\text { Yes } \\
\text { Yes }\end{array}$ & $\begin{array}{c}\text { Not done } \\
3.1\end{array}$ & $\overline{\bar{z}}$ & Recovery in 21 days \\
\hline 11 & 66 & $M$ & $\begin{array}{l}\text { Vesical calculi } \\
\text { ?Perforation of bladder } \\
\text { Retention of urine }\end{array}$ & $\begin{array}{r}5.6 .68 \\
12.6 .68 \\
26.6 .68\end{array}$ & $\begin{array}{l}\text { Cystoscopy } \\
\text { Laparotomy } \\
\text { Transurethral prostatectomy }\end{array}$ & $\overline{\frac{7}{6}}$ & $\begin{array}{l}\text { Yes } \\
\text { Yes } \\
\text { Yes }\end{array}$ & $\overline{\overline{14 \cdot 8}}$ & $\overline{1, \overline{116}}$ & Death after 13 days \\
\hline
\end{tabular}

*Interval to first episode of jaundice

tInterval to second episode of jaundice

$+\dagger$ Jaundiced on morning of operation

Only one (Case 7) had had blood transfusion, and none had been exposed to a case of jaundice or to a known hepatotoxic agent during the previous year. Four of the patients had two exposures to halothane, six had three, and one had four exposures before the onset of their final illness. In nine patients unexplained fever occurred after the penultimate anaesthetic. The other two patients were also febrile before their final anaesthetic, but in these instances causes other than halothane were evident.

Three of the patients had been jaundiced following previous anaesthetics with halothane. Case 2 developed jaundice with serum bilirubin of $5.2 \mathrm{mg} / 100 \mathrm{ml}$ and serum aminotransferase of $120 \mathrm{IU} / 100 \mathrm{ml} 18$ days after a muscle biopsy under halothane anaesthesia had been carried out in the investigation of an undiagnosed illness. Liver function had been normal before that anaesthetic. The jaundice had remitted by the time of the second anaesthetic given ten days later for biopsies of lymph node and liver. Three days after this operation jaundice reappeared; it deepened rapidly and the patient died in hepatic coma 14 days later.

Case 4 was found to have icteric sclerae on the morning of her third operation, which was for the evacuation of impacted faeces. Thereafter, the jaundice increased rapidly reaching a peak 18 days later. She then slowly improved.

Case 10 had become jaundiced in 1965 following an appendicectomy, this being carried out five weeks after an operation for varicose veins. Two years later a cystadenoma of breast was excised, following which she had an unexplained febrile illness lasting 10 days. Three months later she had a fourth operation under halothane anaesthesia for dilatation and curettage for a uterine polyp. Postoperatively she again became febrile, and on the 10th day was found to have hepatitis, from which she recovered in three weeks.

The course of the illness of the six patients who died was typical of massive hepatic necrosis. Those who survived did not develop coma and lost their jaundice over a three-week to six-week period.

\section{Laboratory and Pathological Findings}

The biochemical findings were those of acute hepatitis with raised serum enzyme levels, and in the fatal cases a markedly prolonged prothrombin time. Peripheral blood eosinophilia was not seen. Mitochondrial antibodies ${ }^{14}$ were found in the serum in high titre in three (Cases 3,6 , and 7) of the four patients tested. Liver scintiscanning using technetium $99 \mathrm{~m}-$ labelled sulphur colloid was carried out in seven patients. All the fatal cases showed a definite reduction in liver size; in the non-fatal cases liver size was only slightly reduced.

The weight of the liver at necropsy ranged from 600 to 1,280 in the fatal cases. An unsuspected finding in Case 1 was a coarse, multilobular cirrhosis, but in addition histological examination showed massive necrosis of the parenchymal cells. The other fatal cases had massive cellular necrosis with small areas of surviving cells at the periphery of the lobules. Mild to moderate infiltration with polymorphonuclear cells, lymphocytes, and plasma cells was seen in the portal zones, but eosinophils were not conspicuous. Needle biopsies of the liver, obtained in Cases 3 and 4 during recovery from the hepatitis, showed similar but less pronounced changes.

\section{Discussion}

There seems little doubt that halothane was responsible for the hepatitis in the patients described. As in other series, the majority had more than one exposure before the onset of jaundice. Trey and his colleagues ${ }^{15}$ have pointed out that, whereas the chances of a patient who has had a general anaesthetic having a second anaesthetic within the subsequent two months is $9 \%, 77 \%$ of their patients with massive hepatic necrosis following halothane had multiple exposures within this time. All our patients had fever after their earlier operations; in all but two it had no obvious cause. Two had previously had episodes of jaundice after halothane anaesthesia. The occurrence of second attacks after reexposure and the greater severity of these strongly implicate halothane as their cause ${ }^{6}$.

Frequently surgical patients have other conditions predisposing to liver failure, and there is a tendency to attribute liver failure to these rather than to halothane. One of our patients was found at necropsy to have cirrhosis. Surgery can of course precipitate liver failure in patients with previously compensated liver disease, but the operations in our patient were relatively minor and were uneventful. Furthermore, he had unexplained fever after the second opera- 
tion, and it was after the third operation that he developed the massive hepatic necrosis which was responsible for his death. Case 6 had an episode of hypotension during her second operation, but this is unlikely to have been the cause of her liver necrosis since she did not develop renal failure at the same time. The finding of mitochondrial immunofluorescent antibody in her serum also supports the diagnosis of halothane hepatitis ${ }^{5}{ }^{16}$.

The rarity of liver damage following halothane is explicable on the assumption that it is a hypersensitivity reaction occurring only in certain predisposed subjects. Evidence for an immunological pathogenesis is its relationship to multiple rather than single exposures; the earlier onset of second and subsequent attacks; the association of fever; the frequent finding of circulating and tissue eosinophilia; and in many cases the presence of mitochondrial antibodies. Direct evidence in favour of a cell-mediated immune mechanism has been obtained by Paronetto and Popper, ${ }^{17}$ who found that lymphocytes from affected patients underwent transformation in vitro when halothane was used as the antigen.

At present halothane is the most widely used general anaesthetic. Though its desirable properties outweigh the small risk of liver damage, we would suggest that its use could be made even safer and that the occurrence of hepatic necrosis could be largely prevented, for it only occasionally occurs after a single anaesthetic. Twenty-seven of the 35 patients of Trey and his colleagues, ${ }^{15} 30$ of the 42 patients reported by Klion and his colleagues, ${ }^{5}$ and all of our patients had two or more anaesthetics with halothane before developing massive hepatic necrosis. Furthermore, all but one of our patients had clinical features-jaundice, fever, or bothafter earlier anaesthetics which could have alerted to the possibility of halothane hepatotoxicity and prevented further exposure. For example, one of our patients (Case 9) required two further operations a year after her attack of hepatitis, but agents other than halothane were used for anaesthesia and neither of the operations was complicated by fever or jaundice.
Multiple halothane anaesthetics should not be given within a short period of time without a careful study of the previous postoperative course. Though fever during the first few days after major surgical procedures is common, unexplained fever-particularly if lasting longer than five days or occurring following an afebrile interval after operation ${ }^{18}$ - should be a deterrent to its further use. However, temperature charts are often discarded after the patient's discharge from hospital and anaesthetic records are usually kept on separate forms, which often become separated from the case folder. Furthermore, the important preoperative examination of the patient by the anaesthetist is still sometimes omitted. For these reasons we believe that halothane hepatitis is a definite entity, that its frequency is higher than currently accepted, and that most cases could be prevenied.

\section{References}

' Burnap, T. K., Galla, S. J., and Vandam, L. D., Anesthesiology, 1958' 19,307

${ }^{2}$ Virtue, R. W., and Payne, K. W., Anesthesiology, 1958, 19, 562.

Mushin, W. W., Rosen, M., Bowen, D. J., and Campbell, H., British Medical fournal, 1964, 2, 329.

- Committee on Anesthesia, National Academy of Sciences and National Research Council, fournal of the Academy of Sciences and National 197, 775 .

' Klion, F. M., Schaffner, F., and Popper, H., Annals of Internal Medicine, $1969,71,467$.

- Tygstrup, N., Lancet, 1963, 2, 466.

' Hughes, M., and Powell, L. W., Gastroenterology, 1970, 58, 790. Klatskin, G., and Kimberg, D. V., New England fournal of Medicine, $1969,280,515$

10 Trey, C., Lipworth, L., and Davidson, C. S., Gastroenterology, 1970 $58,306$.

11 Stephen, C. R., New England fournal of Medicine, 1969, 280, 561.

2 Lorhan, P. H., New England fournal of Medicine, 1969, 280, 562

13 Allen, H. L., New England fournal of Medicine, 1969, 280,562

4 Doniach, D., Riott, I. M., Walker, J. G., and Sherlock, S., Clinical and Experimental Immunology, 1966, $1,237$.

15 Trey, C., et al., New England fournal of Medicine, 1968, 279, 798 16 Rodriguez, M., Paronetto, F., Schaffner, F., and Popper, H., Journal of

17 Paronetto, F., and Popper, H., New England Journal of Medicine, 1970, 283, 277 . ${ }^{18}$ Klion, F. M., Schaffner, F., and Paronetto, F., Gastroenterology, 1969,

\title{
Hospital Topics
}

\section{Minor Gynaecological Outpatient Operations}

\author{
H. WAGMAN, D. S. BAMFORD
}

British Medical fournal, 1971, 1, 450-451

\begin{abstract}
Summary
Altogether 143 patients had minor gynaecological operations performed under general anaesthesia in the outpatient department. This method proved to be very acceptable to patient, gynaecologist, and anaesthetist. No complications occurred requiring admission to hospital, and the short recovery time confirmed the safety of early discharge from hospital. This
\end{abstract}

Obstetric and Gynaecological Unit, the London Hospital, London E.1 H. WAGMAN, F.R.C.S.ED., M.R.C.O.G., Registrar

D. S. BAMFORD, F.R.C.S.ED., M.R.C.O.G., Senior Registrar procedure had a beneficial effect on the waiting list, and expensive beds were used more efficiently for major surgical cases. It is recommended that this procedure should be more widely practised, provided that the patients are adequately screened.

\section{Introduction}

Limited numbers of beds, restricted theatre time, and increasing work load are common problems in gynaecological departments of many hospitals at a time when the cost of inpatient care is rising steeply. In this teaching hospital the waiting list has been lengthened by the closure of an annexe, so that only urgent and acute cases can be promised early admission. 